\title{
Distance Learning Students' Evaluation of E-Learning System in University of Tabuk, Saudi Arabia
}

\author{
Mefleh Qublan B Al-Juda ${ }^{1}$ \\ ${ }^{1}$ Department of Educational Technology, College of Education, University of Tabuk, Tabuk, Saudi Arabia \\ Correspondence: Mefleh Qublan B Al-Juda, Department of Educational Technology, College of Education, \\ University of Tabuk, P.O. Box: 741, Tabuk, 71491, Saudi Arabia. Tel: 966-555-62-3391. E-mail: \\ Mg.alqahtani@ut.edu.sa
}

Received: June 27, 2017

Accepted: July 13, $2017 \quad$ Online Published: August 10, 2017

doi:10.5539/jel.v6n4p324

URL: http://doi.org/10.5539/jel.v6n4p324

\begin{abstract}
This study evaluates the experiences and perceptions of students regarding e-learning systems and their preparedness for e-learning. It also investigates the overall perceptions of students regarding e-learning and the factors influencing students' attitudes towards e-learning. The study uses convenience sampling in which students of the Education \& Arts and Business Administration colleges were e-mailed the survey. Of the distributed questionnaires, 500 completed were received and analysed. The findings revealed that the majority of the sampled participants used and benefited from the e-learning system. The results also indicated that students underwent an adequate training program provided by the University on the use of e-learning. Furthermore, the results disclosed that participants reasonably received technical support when they used electronic cards on e-learning web portals. In addition, regression analysis found that only recorded lectures help to compensate for the virtual class, manuals, instructions and guidelines published at web portals, and the easiness of e-learning system provided by the University were statistically significant with the positive attitude towards the e-learning system. The findings provided a preliminary framework for future studies on e-learning systems across Saudi universities. The findings also suggest administrators, researchers, decision makers, and policy makers should properly plan, design, implement, and promote e-learning with a clear vision in Saudi Arabia.
\end{abstract}

Keywords: e-learning, distance learning system, e-courses, educational web portals, students' perspective

\section{Introduction}

The revolution in computer and information technology has opened several opportunities in different fields of life including government departments, educational institutions, and business enterprises. In business organizations, information technology and other e-portals are used as a network of communication. Therefore, various business organizations and other institutions have developed their websites and online advertising systems. In addition to these, the development of the internet has revolutionized the basic form of education; i.e., the conventional face-to-face system of education has changed (Chen \& Wang, 2005). Chen and Wang (2005) established a cyber-schooling framework as a tool to overcome the shortcomings of time and limited space in the conventional education system. According to Anderson, Boyles, and Rainie (2012), academic stakeholders see technology as a tool improving teaching and learning experiences in educational institutions (Anderson, Boyles, \& Rainie, 2012).

In recent years, a special emphasis has been given to e-learning systems and services in educational institutions and industrial sectors (Johnson, 2014). After careful consideration of the introduction of technology in education, it is believed to become one of the largest contributing sector in the world economy. E-learning improves the performance, knowledge, and skills of young learners (Usoro \& Abid, 2008). E-learning is also seen to reduce the cost of education and improve access to quality education (Laurillard, 2007). Considerable research and development in e-learning have created a body of books, referenced journals, articles, and reports on web portals to improve e-learning experiences. Various factors are identified in the e-learning theoretical framework that influence the quality of e-learning courses. These key components include technology, pedagogy, and organizational context (Chai, Koh, Lim, \& Tsai, 2014). All these factors must be aligned in such a way to enhance the quality of e-learning. 
There are various definitions of an e-learning system. An e-learning system is a form of online learning that occurs in a formal context with the use of multimedia technologies (Anderson, 2016). According to this definition, e-learning is supported by hardware and software for effective provision of quality education either online or offline. E-learning is also defined as a computer-enhanced learning system which is delivered through personal computers (Chan \& Ranjit, 2005). In this system, different communication technologies and online tutorials are used to deliver education. Thus, effective provision of e-learning is said to be a blend of different processes. Such processes projected addressing dominant theories guiding e-learning activities. Cognitive, constructive and behaviorist theories have dominated learning aspects including e-learning (Haythornthwaite \& Andrews, 2011). Of the foregoing three leading theories and others, this study uses constructive approach, which postulates that learners construct their own knowledge, which is strongly influenced by perilous experiences. Thus, learners build their own individual sense of reality. The approach encourages educators to reflect on their perceptions and to provide experiences that will help learners' current knowledge (Haythornthwaite \& Andrews, 2011; Piaget, 1926; Vygotsky, 1994; Bruner, 1987; Wood, 1998).

In an e-learning system, a significant number of applications and processes are designed in the form of CD-ROM and USB or video-conferencing to provide knowledge to the students. Alternatively, e-learning is also known as a system which utilizes technology in the form of computers, multimedia devices, and the internet to improve the traditional classroom interactions between students and teachers. E-learning is a process of self-study which engages students in online virtual classrooms and various educational activities.

Learning through virtual classrooms improves the satisfaction level of students as different aesthetic, interactive graphics, texts, sound, and video deeply engage the students. In the changing educational environment worldwide, the Higher Education Institutions (HEIs) need to maintain a competitive advantage by providing high-quality teaching services through e-learning systems. HEIs have exploited the field of IT in their e-learning system and at the same time reduced the cost of quality education, which has enabled more students to enroll in e-learning courses (Mohamad Hsbollah, Kamil, \& Idris, 2009). These findings show that e-learning increases the quality of learning and teaching. Recently, the number of IT based education and web-based learning platforms has grown in the HEIs. Traditional classrooms lack mobility and are fixed at a specific locations (Wu \& Chen, 2013). Thus, traditional classrooms limit the opportunity for students to exploit the advantages of developing technology (Chen \& Wang, 2005). In addition, the courses offered in traditional schools start at fixed times and hence limit the interaction between teachers and students. No such limitations exist in e-learning courses, as teachers and students can interact any time via e-learning web portals. The current trend in e-learning suggests that $25 \%$ of the courses in business schools will be delivered on e-learning systems by the end of 2014 (Haverila \& Barkhi, 2009). As such, it is important to optimize technology in the education setup to facilitate the teaching and learning experiences beyond boundaries.

One of the reports produced by Oxford University Department for Continuing Education revealed that several issues have emerged in e-learning and distance learning programs such as high cost, lack of agility, and infrastructure which needs to be improved to make e-learning system an efficient system of education. The learning experience can be enriched through technologies, as it offers more opportunities than a face-to-face approach to education (Mellema, Smart, Shull, \& Salmona, 2009). The students' level of satisfaction regarding e-learning systems increases when they get easy access to technology. The university needs to provide reliable equipment to the students to ensure smooth delivery of e-learning courses (Kuo, Walker, Schroder, \& Belland, 2014). Furthermore, it is important that online learners be familiar with the use of technology to get the full benefit of an e-learning system (Er, Liaw, Lim, \& Marimuthu, 2015). Students get frustrated when they are not familiar with the technology, and it lowers their satisfaction level (Bidder, Mogindol, Saibin, Andrew, \& Naharu, 2016). Similarly, a high level of technical support is required for the students to use the published sources on e-learning web portals properly. It is therefore important to improve the e-learning experience of students to enhance their e-learning readiness and acceptance (Liaw, Huang, \& Chen, 2007; Selim, 2007). The present study was conducted to address the prospects of e-learning initiatives in Saudi Arabia. The study investigated the experience and perception of students regarding an e-learning system and their preparedness for e-learning. The present study also shows the overall perspective of students regarding e-learning and outlines the factors which influence the student's attitude towards e-learning. 


\subsection{Significance of the Study}

It is observed that prion to this study, few studies have investigated the perception of students and teachers regarding online education in different parts of Gulf countries. Arguably, no research has examined the students' perceptions about e-learning system in Saudi universities and the factors that influence students' attitudes towards e-learning systems. The present study seeks to fill the gap in the e-learning related literature. The present study has both theoretical and practical significance due to the following outcomes:

- The present study provides the knowledge to improve the support services of e-learning systems, the curriculum of e-learning courses and interaction between university teachers and students on e-learning web portals.

- The study also put forward recommendations to facilitate the students' experience with e-learning courses and improve the overall design of e-learning system in the universities.

\subsection{Research Objectives}

The study aims to address specific objectives, which are:

- Determining the level of exposure to e-learning courses of university students.

- Determining the effectiveness of e-learning courses in the university education.

- Determining the benefits and drawbacks of the e-learning system in the university.

\section{Method}

\subsection{Population and Sample}

In the present study, the participants from two colleges, Education \& Arts and Business Administration of University of Tabuk, located in Tabuk, Saudi Arabia were sampled. The University of Tabuk started its distance learning program in 2008. There are total 18,000 students currently enrolled in distance learning programs offered at the University of Tabuk. The present study collected data on students' perceptions regarding e-learning courses from 500 students. The demographic characteristics of the study participants are presented in the results section.

\subsection{Research Questions}

This study examined students' perceptions regarding the e-learning system offered at the University of Tabuk, Saudi Arabia. The results of the present study address the following research questions:

1) What is the general perception of students regarding the e-learning system offered at the University of Tabuk?

2) Is there any significant difference in students' perceptions regarding the e-learning system based on gender?

3) What is the relationship between students' perceptions about virtual classrooms (e-learning system) and the characteristic features of the e-learning system?

\subsection{Instrumentation}

The data of the present study was collected through a survey questionnaire published on the e-learning web portal of the University of Tabuk. The survey questionnaire consisted of two parts, with the first part being demographic characteristics of the participants including the gender, level of education, and college. The second part consisted of the characteristic features associated with the e-learning system such as resources published on e-learning web portals and interaction between students and teachers via e-learning web portals. The questionnaire is available in Appendix A. Cronbach's Alpha test was applied on the survey items to determine the reliability of the items. The reliability results for the items are presented in Appendix B.

\subsection{Research Procedure}

The survey items were published on the e-learning web portals of the University of Tabuk. The students of the colleges of Business Administration and Education \& Arts were asked to record their responses on the survey items available on the web portal. The first section of the survey consisted of four items which recorded the demographic characteristics of the participants. The second section of the survey consisted of fourteen items related to the e-learning system offered at the University of Tabuk. The participants were asked dichotomous questions through closed-ended statements. Participants were asked to indicate that whether they find e-learning web portals beneficial in their educational career. They were also asked whether they find the virtual classroom 
system as an effective system of education or otherwise. After getting responses from 500 participants, the survey was closed from the e-learning web portal of the University of Tabuk.

\subsection{Statistical Analysis}

All the recorded data was analyzed using Statistical Package for Social Sciences (SPSS) Version 20.0. Descriptive statistics was applied to summarize the collected data from respondents. Pearson's correlation test was applied to determine the students' perceptions about the e-learning system offered by the University of Tabuk based on gender. Subsequently, multiple linear regression analysis was applied to examine the relationship between the dependent variable of what participants feel about the virtual classroom system and the characteristics of the e-learning system. In addition to these, the characteristic factors of the e-learning system that are statistically associated with positive students' perceptions were also evaluated. The dependent variable (Y) was students' perceptions about virtual classrooms as a good system; whereas the independent variables included (X1, 2, 3,..., and 8); (a) gender; (b) benefit from the university e-learning system; (c) received training to use e-learning system; (d) manuals, instructions and guidelines to facilitate the use of the e-learning system; (e) recorded lectures compensate for a virtual class; (f) communication system of university via SMS rating; (g) usefulness and relevance of published resources; and (h) interaction with teachers and receipt of proper feedback on web portals.

\section{Results}

The present study evaluated the student's perceptions regarding the effectiveness of the e-learning system in the university. Considering the positive attitude of students towards the e-learning system, it can be deduced that e-learning systems are effective in delivering quality education to students. Table 1 shows the descriptive analysis of demographic variables of the participants included in the study. The majority of the participants in the study were female (63.2\%). Most of the participants in the study were in the third and fourth level of education (45.6\%). In addition, the majority of participants were from the College of Business Administration $(76.8 \%)$.

Table 1. Descriptive statistics of demographic variables, means and standard deviations

\begin{tabular}{lccc}
\hline Variables & Percentage (\%) & Standard deviation & Mean \\
\hline Gender & 36.8 & 0.483 & 0.63 \\
Male & 63.2 & & \\
Female & & & 0.84 \\
Level of Education & 45.6 & 0.855 & \\
Third \& Forth & 24.6 & & \\
Fifth \& Sixth & 29.8 & & \\
Seventh \& Eighth & & & 0.77 \\
Name of College & 23.2 & 0.423 & \\
Education and Arts & 76.8 & & \\
Business Administration & & & \\
\hline
\end{tabular}

When asked about the effectiveness of e-learning system in the university, most of the participants reported in favor of the e-learning system. In the present study, it was found that $77.6 \%$ of the participants use the e-learning system available at the University. $75.8 \%$ reported they get to benefit from the e-learning system of the university. $80.2 \%$ found e-courses published on the web portals of the e-learning system useful. $57.2 \%$ indicated that enough training is provided to them by the university to use the e-learning system of the university properly. $54.8 \%$ participants believed that proper technical support is provided to them when they use their electronic cards on the e-learning web portals. A large number of participants (79\%) consider discussion forums as an important part of e-learning systems. Similarly, $73 \%$ of participants reported that recorded lectures help to compensate for missed virtual classes and $81.8 \%$ found manuals, instructions, and guidelines as valuable sources to adequately use the e-learning web portals. $51.6 \%$ and $56.2 \%$ reported that instructors directly interacted with students through the e-learning web portals and provided feedback respectively. $79.8 \%$ found resources published on the e-learning web portals as relevant to their courses and $67.6 \%$ reported the SMS system used by the University for communication as an efficient and useful system. A large number of participants (72.6\%) 
reported in favor of the virtual classroom system as an excellent system of education. All these results with their standard deviation and means are presented in Table 2.

Table 2. Descriptive statistics about perception of e-learning system

\begin{tabular}{|c|c|c|c|}
\hline Variables & Percentage $(\%)$ & Standard deviation & Mean \\
\hline \multicolumn{4}{|c|}{ Use e-learning system at University } \\
\hline Yes & 77.6 & 0.417 & 0.22 \\
\hline No & 22.4 & & \\
\hline \multicolumn{4}{|c|}{ Get benefit from University's e-learning system } \\
\hline Yes & 75.8 & 0.429 & 0.24 \\
\hline No & 24.2 & & \\
\hline \multicolumn{4}{|c|}{ E-courses published on e-learning web portals are an important reference for me. } \\
\hline Yes & 80.2 & 0.399 & 0.20 \\
\hline No & 19.8 & & \\
\hline \multicolumn{4}{|c|}{ I get enough training within the University to use the e-learning system. } \\
\hline Yes & 57.2 & 0.495 & 0.43 \\
\hline No & 42.4 & & \\
\hline \multicolumn{4}{|c|}{ I get technical support when I insert an electronic card within the e-learning system. } \\
\hline Yes & 54.8 & 0.498 & 0.45 \\
\hline No & 45.2 & & \\
\hline \multicolumn{4}{|c|}{ Discussion forums are considered an important part of e-learning system. } \\
\hline Yes & 79.0 & 0.408 & 0.21 \\
\hline No & 21.0 & & \\
\hline \multicolumn{4}{|c|}{ Recorded lectures help compensate for the virtual class. } \\
\hline Yes & 73.0 & 0.444 & 0.27 \\
\hline No & 27.0 & & \\
\hline \multicolumn{4}{|c|}{$\begin{array}{l}\text { Manuals, guidelines, and instructions on e-learning site facilitate the use of } \\
\text { e-learning web portals. }\end{array}$} \\
\hline Yes & 81.8 & 0.386 & 0.18 \\
\hline No & 18.2 & & \\
\hline \multicolumn{4}{|c|}{ Instructors interact with their students through e-learning web portals. } \\
\hline Yes & 51.6 & 0.500 & 0.48 \\
\hline No & 48.4 & & \\
\hline \multicolumn{4}{|c|}{ Instructors provide feedbacks on e-courses. } \\
\hline Yes & 56.2 & 0.497 & 0.44 \\
\hline No & 43.8 & & \\
\hline \multicolumn{4}{|c|}{ The E-learning system in the University is very easy. } \\
\hline Yes & 78.8 & 0.409 & 0.21 \\
\hline No & 21.2 & & \\
\hline \multicolumn{4}{|c|}{ Resources and activities published on e-learning web portals are useful and relevant. } \\
\hline Yes & 79.8 & 0.402 & 0.20 \\
\hline No & 20.2 & & \\
\hline \multicolumn{4}{|c|}{ The communication system used by the University via SMS is efficient and good. } \\
\hline Yes & 67.6 & 0.468 & 0.32 \\
\hline No & 32.4 & & \\
\hline \multicolumn{4}{|c|}{ The virtual classroom system is a good system. } \\
\hline Yes & 72.6 & 0.446 & 0.27 \\
\hline No & 27.4 & & \\
\hline
\end{tabular}


The descriptive analysis revealed that there is only a slight difference in the perception of e-learning between female and male students. Table 3 shows the correlation analysis, which shows the statistically non-significant difference between the genders. Figure 1 demonstrates the number of male and female students who think the virtual classroom system is good.

Table 3. Correlation analysis of students perception about e-learning system by gender

\begin{tabular}{lllll}
\hline Systematic Measures & Value & Asymptomatic. Std. Error & Approx. $\mathrm{T}^{\mathrm{b}}$ & Approx. Sig. \\
\hline Pearson's R & 0.032 & 0.044 & 0.799 & 0.479 \\
Kappa & 0.024 & 0.034 & 0.710 & 0.478 \\
\hline
\end{tabular}

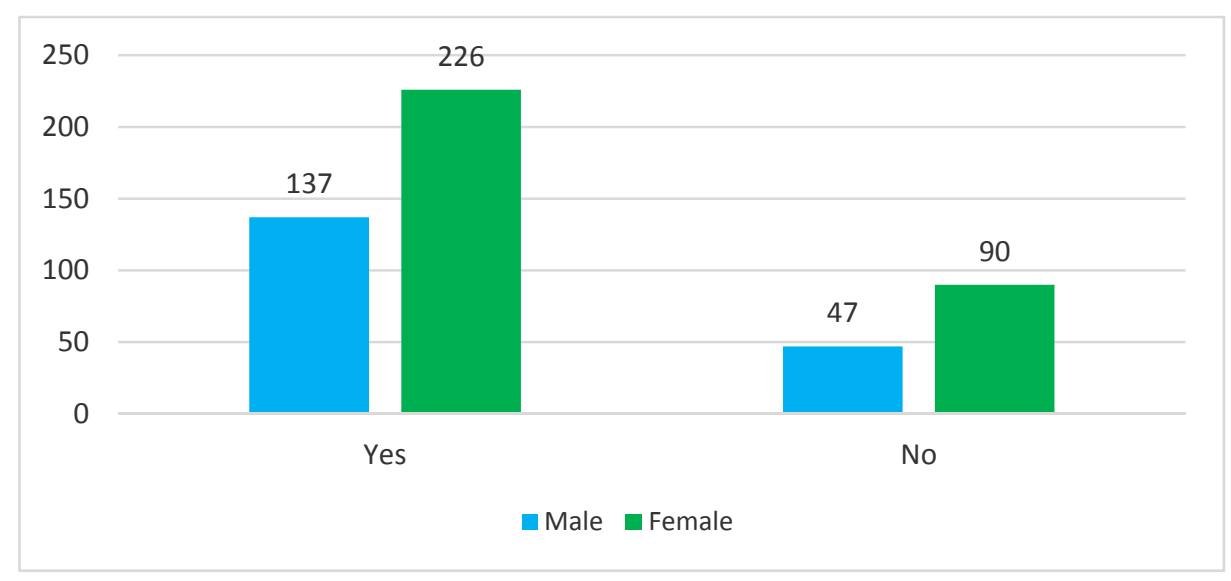

Figure 1. Number of students happy with the virtual classroom system in the University based on gender

To determine the relationship between the students' perception of the e-learning system and various demographic and e-learning system characteristics such as gender, use of SMS for communication in the e-learning system, manuals, instructions and guidelines available on e-learning web portals, and the support and training from the University for the e-learning system, regression analysis was conducted as shown in Table 4. The model was found to be statistically significant $\left(\mathrm{R}^{2}=0.04\right)$ at a significance level of 0.05 as shown in Table 5.

Table 4. ANOVA a analysis

\begin{tabular}{lllllll}
\hline Model & & Sum of Squares & Df & Mean Square & F & Sig. \\
\hline \multirow{3}{*}{1} & Regression & 4.002 & 16 & 0.250 & 1.268 & $0.0213^{\mathrm{b}}$ \\
& Residual & 94.858 & 481 & 0.197 & & \\
& Total & 98.859 & 497 & & & \\
\hline
\end{tabular}

a. Dependent Variable: The virtual classroom system is a good system.

b. Predictors: (Constant), the communication system used by the University SMS is an effective and good system, recorded lectures help to compensate for the virtual class, the resources published on the e-learning web portals are useful and relevant, manuals, instructions, and guidelines that are published on the e-learning web portals facilitate the use of e-learning website, and students get instant support when they insert electronic cards in the e-learning system. 
Table 5. Model summary

\begin{tabular}{lllll}
\hline Model & $\mathrm{R}$ & R Square & Adjusted R Square & Std. Error of the Estimate \\
\hline 1 & $0.201^{\mathrm{a}}$ & 0.040 & 0.009 & 0.444 \\
\hline
\end{tabular}

Table 6 shows that the variable of recorded lectures that help to compensate for virtual class $(t=1.916 ; p=0.05)$, manuals, instructions and guidelines published at web portals $(\mathrm{t}=2.237 ; \mathrm{p}=0.02)$, and the ease of e-learning system provided by the University $(t=2.76 ; p=0.03)$ were found to be statistically significant with the positive attitude towards the e-learning system. However, all other variables were found to be statistically insignificant.

Table 6. Coefficient correlation of variables

\begin{tabular}{|c|c|c|c|c|c|}
\hline \multirow[b]{2}{*}{ Model } & \multicolumn{2}{|c|}{ Unstandardized Coefficients } & \multirow{2}{*}{$\begin{array}{c}\text { Standardized } \\
\text { Coefficients } \\
\text { Beta }\end{array}$} & \multirow[b]{2}{*}{$\mathrm{t}$} & \multirow[b]{2}{*}{ Sig. } \\
\hline & $\mathrm{B}$ & Std. Error & & & \\
\hline Constant & 0.289 & 0.073 & & 3.977 & 0.000 \\
\hline Gender of Students & 0.039 & 0.042 & 0.043 & 0.934 & 0.351 \\
\hline Benefit from University's e-learning system & 0.031 & 0.047 & 0.030 & 0.664 & 0.507 \\
\hline $\begin{array}{l}\text { Sufficient training within the university to } \\
\text { use the e-learning system. }\end{array}$ & 0.037 & 0.041 & 0.041 & 0.891 & 0.374 \\
\hline $\begin{array}{l}\text { Recorded lectures help to compensate for the } \\
\text { virtual class. }\end{array}$ & 0.087 & 0.045 & 0.086 & 1.916 & 0.05 \\
\hline $\begin{array}{l}\text { Manual, instruction, and guidelines published } \\
\text { on the e-learning sites facilitate the use of } \\
\text { e-learning web portals. }\end{array}$ & 0.122 & 0.052 & 0.106 & 2.337 & 0.020 \\
\hline Get enough feedback from professors. & 0.068 & 0.043 & 0.063 & 1.856 & 0.063 \\
\hline $\begin{array}{l}\text { The E-learning system available at the } \\
\text { university is very easy. }\end{array}$ & 0.136 & 0.059 & 0.114 & 2.76 & 0.038 \\
\hline $\begin{array}{l}\text { The communication system used by the } \\
\text { university via SMS is very effective and } \\
\text { good. }\end{array}$ & -0.079 & 0.044 & -0.083 & -1.807 & 0.071 \\
\hline
\end{tabular}

a. Dependent Variable: The virtual classroom system is a good system.

\section{Discussion}

The aim of this study was to evaluate students' perceptions of e-learning courses offered at the University of Tabuk. There are several characteristics of e-learning courses that are associated with student satisfaction. These features help to understand the students' experiences with the e-learning system and also provide recommendations to improve the design and courses of e-learning system at universities.

A descriptive analysis was performed to determine the general perception of students regarding the e-learning system provided at the university. It was found that almost all the participants reported a positive perception of the e-learning system. The findings of the present study were consistent with previous studies, which show that students feel good about e-learning systems (Suri \& Sharma, 2013). Another study conducted in Saudi Universities also revealed a similar positive attitude of students towards e-learning systems (Hussain, 2007). A study carried out in the Gulf also shows positive perceptions of students about e-learning systems (Tubaishat \& Lansari, 2011). The results of the present study as shown in Table 2 are congruent with the previous findings.

The present study also aimed to determine whether differences based on gender exist in students' perceptions regarding the e-learning system offered at the University of Tabuk. The results revealed that there is no statistically significant difference $(\mathrm{R}=0.479)$ in perceptions of female and male students regarding the e-learning system as shown in Table 3. This result is in consonance with the previous studies. Hussein (2011) reported similar attitudes of male and female students towards e-learning systems. Another study shows no substantial difference between males' and females' attitudes towards e-learning (Vandenbroeck, Verschelden, \& Boonaert, 2008). However, few studies conducted in the past demonstrate a more positive attitude of male 
students towards e-learning as compared to the female students (Ong \& Lai, 2006). The present study reveals no difference, which shows that both male and female students get to benefit from e-learning systems and utilize the sources published on the web portals of the e-learning system accordingly.

Furthermore, the findings revealed that there is no statistically significant relationship between the demographic characteristics of the participants such as level of education, and college of education and the positive perceptions of students towards the e-learning system. Similar findings were reported in previous studies, which show that attitude and perceptions of students towards e-learning are not influenced by their level of education and college of education. However, the present study demonstrated a statistically significant relationship between the students' positive perceptions towards the e-learning system or virtual classroom as a good system and the easy access to recorded lectures $(p=0.05)$; manuals, instructions and guidelines published on web portals $(p=0.02)$ at significance level $(p=0.05)$; and the easiness of e-learning system offered by the University of Tabuk $(p=0.03)$ at significance level $(p=0.05)$. The findings also corresponded with previous studies which demonstrated a positive influence on access to technology and ease of use on the students' attitude towards the e-learning system (Papaioannou \& Charalambous, 2011; Paris, 2004; Sweeney \& Geer, 2010). The present study also shows that students' perceptions towards the e-learning system are influenced by the ease of e-learning web portals offered by the university. These results are consistent with Adewole-Odeshi (2014)'s finding, which shows a positive attitude of students when they find e-learning sites easy to use. The present study also indicated that proper training and published manuals, guidelines and instructions facilitate the use of e-learning system. These results are consistent with the previous research, which shows that if students have proper skills to use technologies, they feel good about it and show a positive attitude towards e-learning and ICT (Liaw \& Huang, 2011; Liawa \& Huangb, 2009). One of the pilot studies revealed that the major hurdle in the development of the e-learning system in Saudi Universities is the lack of modern telecommunication and infrastructure (Xanthidis, Wali, \& Nikolaidis, 2013). Similarly, another study revealed that the absence of clear vision and strategic planning in Saudi regarding e-learning systems also slows down the progress of e-learning despite the positive attitude of students towards e-learning (Al-Shehri, 2010). The present study suggested that e-learning should be implemented in universities, as the students feel good about e-learning/virtual classroom systems. However, it is important to provide proper support and training to the students so that they can effectively use e-learning web portals. These findings encourage implementation of the e-learning initiatives in Saudi universities. The results of the present study provide the framework of the future perceptions of students towards e-learning systems at the universities. These results can be used by the administration, researchers, decision makers, and policy makers to properly plan, design, implement and promote e-learning with a clear vision in Saudi Arabia.

However, the present study revealed that it is important to provide appropriate training to the students to help them use the e-learning web portals and gather relevant study resources. These findings are imperative and require special attention from the government to ensure development and implementation of e-learning systems in the universities across Saudi Arabia with adequate training and student awareness.

\section{Conclusion}

In the present study, three distinguishing factors of e-learning systems were found to influence the positive perceptions of students towards e-learning systems. These factors include ease of the e-learning system offered by the University; manuals, instructions and guidelines published at the e-learning web portals to facilitate the use of the e-learning system; and easy access to relevant recorded lectures. These three factors have significant influence on the students' perceptions regarding e-learning. These findings suggest that the university authorities and Ministry of Education, particularly IT department to render more attention to these factors due to their impacts on e-learning distance learning program through e-learning system. Furthermore, the results indicated no significant difference in the perceptions of male and female students regarding e-learning system. The descriptive statistics showed that students received proper training to use e-learning web portals effectively. The interaction between instructors and students also seemed to be improved through e-learning web portals. The study also revealed problems in policy making and design of e-learning systems in Saudi Arabia which need to be overcome through proper policies. This finding suggests that university authorities and the Ministry of Education should revisit e-learning policies and content design to iron out problems affecting the overall effectiveness of e-learning system in the sampled university and others. The results of the present study emphasize the importance of appropriate training, publishing useful resources on e-learning web portals, and improving the overall e-learning system of the university as the key towards the development of quality e-learning systems in Saudi Arabia. 
Despite the significant contributions of this empirical study, there are some limitations need to be addressed. First, this empirical study used a cross-sectional survey method to sample distance learning students of two colleges participated in the study. However, a longitudinal method could give sufficient time to capture the real phenomenon and control issues related to the individual situations concerning e-learning. Second, this study sampled only two faculties and used a quantitative approach. Thus, future studies should include more faculties and use mixed methods approach to capture compressive understanding and other potential factors of the e-learning system. Finally, this study sampled only distance learning students, which is one of the components that constitute e-learning. Therefore, future studies should include e-learning instructors to capture comprehensive e-learning dimensions in Saudi tertiary context.

\section{References}

Adewole-Odeshi, E. (2014). Attitude of students towards E-learning in South-West Nigerian universities: An application of technology acceptance model. Library Philosophy and Practice.

Al-Shehri, A. M. (2010). E-learning in Saudi Arabia: "To E or not to E, that is the question". Journal of Family and Community Medicine, 17(3), 147. https://doi.org/10.4103/1319-1683.74333

Anderson, J. Q., Boyles, J. L., \& Rainie, L. (2012). The future impact of the Internet on higher education. Pew Internet \& American Life Project.

Anderson, T. (2016). Theories for learning with emerging technologies. Emerging Technologies in Distance Education.

Bidder, C., Mogindol, S. H., Saibin, T. C., Andrew, S. A., \& Naharu, N. (2016). Students' perceptions of blended learning and achievement. In Envisioning the Future of Online Learning (pp. 213-225). Springer. https://doi.org/10.1007/978-981-10-0954-9_19

Bruner, J. (1987). Prologue to the English Edition. In R. W. Rieber, \& A. S. Carton (Eds.), the collected works of L. S. Vygotsky, Volume 1, Problems of General Psychology. New York: Plenum Press. https://doi.org/10.1007/978-1-4613-1655-8_1

Chai, C. S., Koh, E., Lim, C. P., \& Tsai, C.-C. (2014). Deepening ICT integration through multilevel design of technological pedagogical content knowledge. Journal of Computers in Education, 1(1), 1-17. https://doi.org/10.1007/s40692-014-0002-1

Chan, Y., Ranjit, K., Jamiah, B., \& Eliza, P. (2007). Computer Education for Classroom Teaching. Malaysia: McGraw-Hill.

Chen, N.-S., \& Wang, Y.-H. (2005). Cyber Schooling framework: Improving mobility and situated learning. Paper presented at the Advanced Learning Technologies, 2005, ICALT 2005, Fifth IEEE International Conference on.

Er, A. N., Liaw, S. C., Lim, T. H., \& Marimuthu, R. (2015). Blended to satisfaction: Factors influencing student satisfaction in a language classroom/Er Ann Nah...[et al.]. Esteem Academic Journal, 11(2), 55-73.

Haverila, M., \& Barkhi, R. (2009). The influence of experience, ability and interest on eLearning effectiveness. European Journal of Open, Distance and E-learning, 12(1).

Hussain, I. (2007). A study of student's attitude towards virtual education in Pakistan. Turkish Online Journal of Distance Education, 8(2).

Haythornthwaite, C., \& Andrews, R. (2011). E-learning theory and practice. London: SAGE Publications Ltd. https://doi.org/10.4135/9781446288566

Johnson, D. J. (2014). A comparison of online education versus traditional education in terms of federal employee performance in an agency within the Department of Defense (DoD). Capella University.

Kuo, Y.-C., Walker, A. E., Schroder, K. E., \& Belland, B. R. (2014). Interaction, Internet self-efficacy, and self-regulated learning as predictors of student satisfaction in online education courses. The Internet and Higher Education, 20, 35-50. https://doi.org/10.1016/j.iheduc.2013.10.001

Laurillard, D. (2007). Modelling benefits-oriented costs for technology enhanced learning. Higher Education, 54(1), 21-39. https://doi.org/10.1007/s10734-006-9044-2

Liaw, S.-S., \& Huang, H.-M. (2011). A study of investigating learners attitudes toward e-learning. Paper presented at the 20115 th International Conference on Distance Learning and Education. 
Liaw, S.-S., Huang, H.-M., \& Chen, G.-D. (2007). Surveying instructor and learner attitudes toward e-learning. Computers \& Education, 49(4), 1066-1080. https://doi.org/10.1016/j.compedu.2006.01.001

Liawa, S.-S., \& Huangb, H.-M. (2009). Gender difference, computer experience, self-efficacy, motivation and intention towards e-learning: A case study of the Blackboard system.

Mellema, H. N., Smart, K. L., Shull, C. M., \& Salmona, M. (2009). Blended learning and user satisfaction. Issues in Information Systems, X(1), 126-130.

Mohamad Hsbollah, H., Kamil, \& Idris, M. (2009). E-learning adoption: The role of relative advantages, trialability and academic specialisation. Campus-Wide Information Systems, 26(1), 54-70. https://doi.org/10.1108/10650740910921564

Ong, C.-S., \& Lai, J.-Y. (2006). Gender differences in perceptions and relationships among dominants of e-learning acceptance. Computers in Human Behavior, 22(5), 816-829. https://doi.org/10.1016/j.chb.2004.03.006

Papaioannou, P., \& Charalambous, K. (2011). Principals' attitudes towards ICT and their perceptions about the factors that facilitate or inhibit ICT integration in primary schools of Cyprus. Journal of Information Technology Education, 10(1), 349-369.

Paris, P. G. (2004). E-Learning: A study on secondary students' attitudes towards online web assisted learning. International Education Journal, 5(1), 98-112.

Piaget, J. (1926). The language and thought of the child. London: Routledge and Kegan.

Selim, H. M. (2007). Critical success factors for e-learning acceptance: Confirmatory factor models. Computers \& Education, 49(2), 396-413. https://doi.org/10.1016/j.compedu.2005.09.004

Suri, G., \& Sharma, S. (2013). The impact of gender on attitude towards computer technology and e-learning: An exploratory study of Punjab University, India. International Journal of Engineering Research, 2(2), 132-136.

Sweeney, T., \& Geer, R. (2010). Student capabilities and attitudes towards ICT in the early years. Australian Educational Computing, 25(1), 18.

Tubaishat, A., \& Lansari, A. (2011). Are students ready to adopt e-learning? A preliminary e-readiness study of a university in the Gulf Region. International Journal of Information and Communication Technology Research, 1(5).

Usoro, A., \& Abid, A. (2008). Conceptualising quality e-learning in higher education. E-learning and Digital Media, 5(1), 75-88. https://doi.org/10.2304/elea.2008.5.1.75

Vandenbroeck, M., Verschelden, G., \& Boonaert, T. (2008). E-learning in a low-status female profession: The role of motivation, anxiety and social support in the learning divide. Journal of Computer Assisted Learning, 24(3), 181-190. https://doi.org/10.1111/j.1365-2729.2007.00252.x

Vygotsky, L. S. (1994). The socialist alteration of man. In R. van de Veer, \& J. Valsiner (Eds.), The Vygotsky Reader. Blackwell Publishers.

Wood, D. (1998). How children think and learn. Oxford: Blackwell Publishers Limited.

Wu, I.-C., \& Chen, W.-S. (2013). Evaluating the E-learning platform from the perspective of knowledge management: The AHP approach. Journal of Library and International Studies, 11(1), 1-24.

Xanthidis, D., Wali, S. W., \& Nikolaidis, P. (2013). E-Learning in Saudi Universities, Challenges and Issues. Paper presented at the e-Learning 2013 Fourth International Conference on Best Practices in Management, Design and Development of e-Courses: Standards of Excellence and Creativity. 


\section{Appendix A}

\section{Survey Questionnaire}

Part 1

Name of the participant:

Gender:

Male $\square \quad$ Female

Level of Education:

Third \& Forth $\quad \square \quad$ Fifth \& Sixth $\quad \square \quad$ Seventh \& Eighth

\section{College:}

Education \& Arts

$$
\text { Business Administration }
$$

\section{Part 2:}

Did you get benefit from the university's e-learning system?

Yes

No

Do you continuously use the e-learning system located at the University web portal?

Yes $\quad \square \quad$ No

E-courses published on the e-learning system are important source of references for me?

Yes $\quad \square \quad$ No

Did you get enough training within the university to properly use the e-learning system?

Yes $\square \quad$ No

When you insert your electronic card for technical support within the e-learning system you get quick response?

Yes $\quad \square \quad$ No

Discussion forums are considered as an important part of the e-learning system?

Yes $\quad \square \quad$ No

Recorded lectures on e-learning system helps to compensate the missed virtual class?

Yes $\quad \square \quad$ No

Manuals, instructions and guidelines that are published on the e-learning site facilitate the use of the site and from its services?

Yes $\quad \square \quad$ No

You get enough feedback from the professors on the e-courses?

Yes $\quad \square \quad$ No

Professors directly interact with the students through e-learning system?

Yes $\quad \square \quad$ No

E-learning system available at the university is very easy?

Yes $\quad \square \quad$ No

The resources and activities published on the web portals of e-learning system are very useful and relevant to the course?

Yes $\quad \square \quad$ No

The virtual classroom system is good system?

Yes $\square \quad$ No

The communication system of SMS used by the university is an effective and good system?

Yes $\quad \square \quad$ No 


\section{Appendix B}

Reliability Analysis

\begin{tabular}{|c|c|}
\hline Variable & Cronbach's Alpha \\
\hline Did you get any benefit from university e-learning system? & 0.76 \\
\hline $\begin{array}{l}\text { Do you use the e-learning system located at the university } \\
\text { continuously? }\end{array}$ & 0.52 \\
\hline $\begin{array}{l}\text { E-courses published on the e-learning system are an important } \\
\text { reference for me? }\end{array}$ & 0.98 \\
\hline $\begin{array}{l}\text { Did you get enough training within the university to use the } \\
\text { e-learning system? }\end{array}$ & 0.61 \\
\hline $\begin{array}{l}\text { When you insert an electronic card for technical support within the } \\
\text { e-learning system you get quick response? }\end{array}$ & 0.81 \\
\hline $\begin{array}{l}\text { Discussion forums are considered an important part of the e-learning } \\
\text { system? }\end{array}$ & 0.76 \\
\hline Recorded lectures help to compensate for the missed virtual class? & 0.64 \\
\hline $\begin{array}{l}\text { Manuals, instructions and guidelines published on the e-learning site } \\
\text { facilitate the use of the site and students benefit from it? }\end{array}$ & 0.87 \\
\hline Get enough feedback from professors? & 0.87 \\
\hline $\begin{array}{l}\text { Professors directly interact with the students through e-learning web } \\
\text { portals? }\end{array}$ & 0.80 \\
\hline E-learning system available at the university is very easy to use? & 0.78 \\
\hline $\begin{array}{l}\text { The resources and activities published on the e-learning web portals } \\
\text { are relevant and useful? }\end{array}$ & 0.91 \\
\hline The virtual classroom system is a good system? & 0.87 \\
\hline $\begin{array}{l}\text { The communication system of SMS used by the university is a good } \\
\text { and effective system? }\end{array}$ & 0.73 \\
\hline
\end{tabular}

\section{Copyrights}

Copyright for this article is retained by the author(s), with first publication rights granted to the journal.

This is an open-access article distributed under the terms and conditions of the Creative Commons Attribution license (http://creativecommons.org/licenses/by/4.0/). 